\title{
Incidence of two leaf fungal diseases in two plum training systems
}

\author{
Molnár, B. ${ }^{1}$, Varga, M. ${ }^{1}$, Vámos A. ${ }^{1}$ \& Holb, I. J. ${ }^{1,2}$ \\ ${ }^{1}$ University of Debrecen, Institute of Horticulture P.O. Box 36, H-4015 Debrecen, Hungary \\ ${ }^{2}$ Plant Protection Institute, Centre for Agricultural Research, Hungarian Academy of Sciences, \\ P.O. Box 102, H-1525 Budapest, Hungary \\ Author for corresponding: Holb, I. J. (holbimre@gmail.com)
}

\begin{abstract}
Summary: In a two-year study, we aimed to determine the susceptibility of four plum cultivars to two fungal pathogens of plum (Stigmina carpophila and Polystigma rubrum) in two training systems with tree spacings of $4 \times 1.5 \mathrm{~m}$ and $6 \times 3 \mathrm{~m}$. Results showed that shothole symptoms were not detected on cvs 'Bluefre' and 'Stanley' in August, 2016. Disease incidence was above 50\% in the case of 'Čačanska lepotica' in both training systems in 2016. There were no significant difference between the two training systems. Shot hole incidence was lower in the $6 \times 3 \mathrm{~m}$ spacings compared to the $4 \times 1.5 \mathrm{~m}$ spacings on cv 'President' in 2016. Cultivar 'Čačanska lepotica' showed the highest incidence of Stigmina carpophila in the $4 \times 1.5 \mathrm{~m}$ spacing in 2017. Disease incidence of Stigmina carpophila was significantly lower in the $6 \times 3 \mathrm{~m}$ spacing compared to the $4 \times 1.5 \mathrm{~m}$ spacing. Shothole incidences on cv 'President' were similar to the values in 2016 ranging from $40 \%$ to $60 \%$. Leaf disease incidence was higher in the $4 \mathrm{x} 1.5 \mathrm{~m}$ spacing compared to the 6 x $3 \mathrm{~m}$ plot. Low disease incidence (below 10\%) was observed on cv 'Stanley' in 2017 and only in the 4 x $1.5 \mathrm{~m}$ spacing. There were no visible symptoms of blackhorn dotty in 2016 due to inadequate weather conditions for the Polystigma rubrum fungus. However, all the four cultivars were infected by Polystigma rubrum in 2017. The most susceptible cultivar was cv 'Čačanska lepotica' with the highest disease incidence in the $4 \mathrm{x} 1.5 \mathrm{~m}$ spacing. Disease incidence of this cultivar was lower in the $6 \times 3 \mathrm{~m}$ spacing which was significantly less than in the $4 \times 1.5 \mathrm{~m}$ spacing. The least susceptible cultivar was 'Bluefre' and symptoms were observed only in the spacing of $4 \mathrm{x} 1.5 \mathrm{~m}$. The disease incidence of cv 'President' was similarly low to cv 'Stanley' in both spacings.
\end{abstract}

Molnár, B., Varga, M., Vámos, A. \& Holb, I. J. (2018): Some features of plum leaf and fruit in two training systems. International Journal of Horticultural Science 24(3-4): 15-17. https://doi.org/10.31421/IJHS/24/3-4./2046

Key words: plum, Stigmina carpophila, Polystigma rubrum, training system

\section{Introduction}

European plum (Prunus domestica L.) is the second largest fruit crops in Hungary. Disease management of plum covers only a few (5-9) sprays during the season and harvested fruit is used mainly for industrial purpose (Holb, 2005; Földes et al., 2015). As plum orchards do not receive intensive spraying program, plum trees are usually under a higher disease pressure and incidence of foliar and fruit fungal diseases are high. Most sprays during the season are used to prevent damage caused by plum moth (Grapholita funebrana L.) which also prevent infection of Monilinia sp. on fruit. Foilar fungal diseases receive no or little attention during the season. The most important foliar diseases of plum in Hungary are shothole disease (Stigmina carpophila L.), and blackhorn dotty (Polystigma rubrum L). Stigmina carpophila causes small holes in developing leaves and causes leaf fall around harvest (Teviotdale et al., 1989; Adaskaveg et al., 1990; Adaskaveg, 1995; Ahmadpour et al., 2006; Ivanová et al., 2012; Yousefi and Hagian Shahri, 2014). Reaction of plum cultivars to shoot hole was assessed previously (Bubici et al., 2010). Polystigma rubrum causes large red spots on leaves (Borovinova, 2002).

Only few study assessed foliar diseases of plum although the diseases can have either a direct or indirect effect on leaf health and fruit quality. In Hungary, $90 \%$ of plum producers still grow conservative cultivars (e. g. 'Bluefre', 'Čačanska', 'President' and 'Stanley') and use old-fashioned extensive training system with spacings over $5 \times 3 \mathrm{~m}$. Most of these cultivars are highly susceptible to plum pox potyvirus. Training system were studied previously and authors stated that spray applications are not effective enough in large trees in the extensive training systems against foliar diseases (Mika et al., 1998; Milosevic et al., 1998).

The aim of this study was to determine the susceptibility of four traditional plum cultivars ('Bluefre', 'Čačanska', 'President' and 'Stanley') to two fungal pathogens of plum (Stigmina carpophila and Polystigma rubrum) in a low density $(6 \times 3 \mathrm{~m})$ and in a high density $(4 \times 1.5 \mathrm{~m})$ training systems.

\section{Materials and methods}

Orchard site

The study was conducted in an experimental plum orchard near Debrecen in Eastern Hungary in 2016 and 2017. Orchard was established in 1997 and trees were grafted on Myrobalan 'C 359' rootstock. Orchard soil type was sandy loam. The orchard consisted of four cultivars ('Bluefre', 'Čačanska lepotica', 'President' and 'Stanley'). Each cultivar was planted a 0.25 ha plot replicated four times. The orchard was managed under integrated fruit growing guidelines.

Trees were planted in a 0.25 ha plots replicated four times. Trees were planted in a low density $(6 \times 3 \mathrm{~m})$ and in a high density $(4 \times 1.5 \mathrm{~m})$ training systems. Trees were planted in 8 rows, one spacing means 2 rows. The $4 \times 1.5 \mathrm{~m}$ plot spacing has a 1667 tree per hectare. The $6 \times 3 \mathrm{~m}$ plot consisted 556 trees per hectare. 


\section{Spraying schedule}

The orchard received 6 and 5 fungicide treatments in 2016 and 2017 respectively. In 2016 sprayings started from 8 March and continued until the 3 August, while in 2017 the first spraying occurred on 4 April and the last on 30 June.

\section{Disease assessments}

Four trees of each cultivar-training system plot were assessed at the end of August in 2016 and at the beginning of September in 2017. Twenty five leaves were selected randomly on each tree, giving a total of 100 leaves per plot. Stigmina carpophila and Polystigma rubrum were assessed on leaves. A leaf was considered to be diseased if one spot was already visible on its surface (Figures 1 and 2).
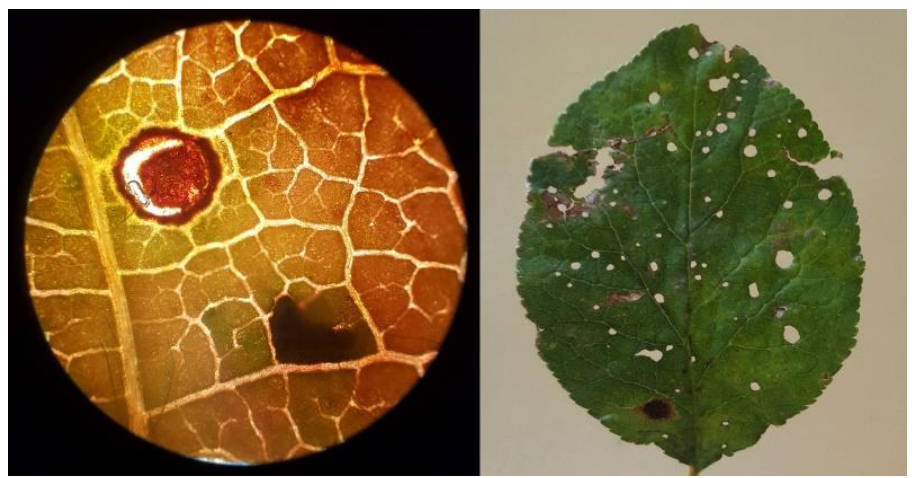

Figure 1. Symptoms caused by Stigmina carpophila on leaves of cultivar 'Čačanska lepotica' (right) and under stereo microscope (60x) (left).

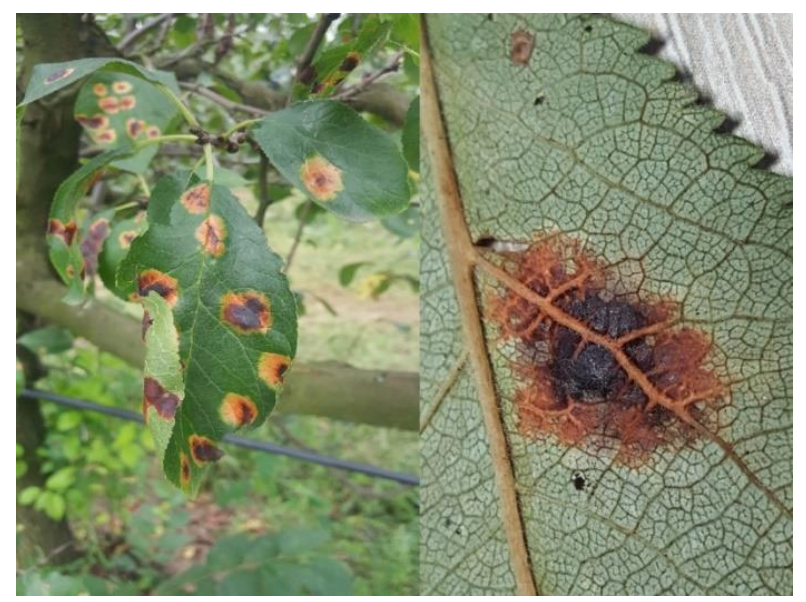

Figure 2. Symptoms caused by Polystigma rubrum on leaves of cultivar 'Čačanska lepotica'.

\section{Data analyses}

Incidence of Stigmina carpophila and Polystigma rubrum on leaf were calculated. ANOVA were used to evaluate the effect of training system and cultivar on disease incidence. Means were separated with LSD t-test at 0.05 level.

\section{Results}

Incidence of Stigmina carpophila

Shothole symptoms were not detected on cvs 'Bluefre' and 'Stanley' in August, 2016. Disease incidence was above 50\% in the case of 'Čačanska lepotica' in both training systems in 2016 (Figure 3). There were no significant difference between the two training systems. Shot hole incidence was lower in the $6 \times 3 \mathrm{~m}$ spacings compared to the $4 \times 1.5 \mathrm{~m}$ spacings on $\mathrm{cv}$ 'President' in 2016.

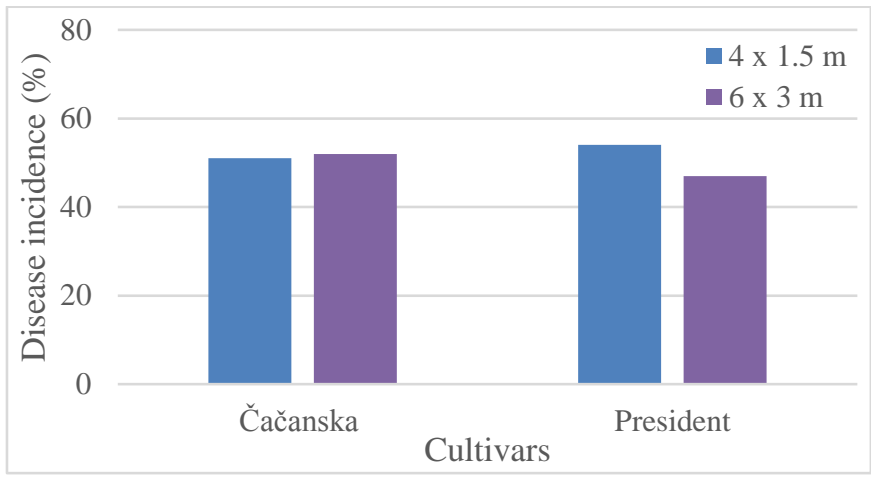

Figure 3. Incidence of shothole disease caused by Stigmina carpophila in 2016 (Debrecen-Pallag).

Cultivar 'Čačanska lepotica' showed the highest incidence of Stigmina carpophila in the $4 \times 1.5 \mathrm{~m}$ tree spacing in 2017. Disease incidence of Stigmina carpophila was significantly lower in the $6 \times 3 \mathrm{~m}$ spacing compared to the $4 \times 1.5 \mathrm{~m}$ spacing (Figure 4). Shot hole incidences on cv 'President' were similar to the values in 2016 ranging from $40 \%$ to $60 \%$. Leaf disease incidence was higher in the $4 \times 1.5 \mathrm{~m}$ spacing compared to the $6 \times 3 \mathrm{~m}$ plot. Low disease incidence (below 10\%) was observed on cv 'Stanley' in 2017 , but only in the $4 \times 1.5 \mathrm{~m}$ spacing.

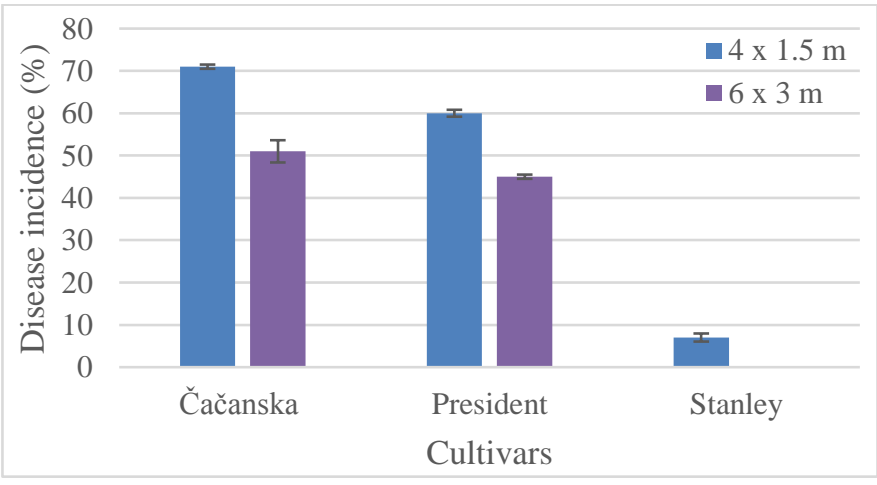

Figure 4. Incidence of shothole disease caused by Stigmina carpophila in 2017 (Debrecen-Pallag)

Incidence of Polystigma rubrum

There were no visible symptoms of blackhorn dotty in 2016 due to inadequate weather conditions for the Polystigma rubrum fungus. However, all the four cultivars were infected by Polystigma rubrum in 2017 (Figure 5).

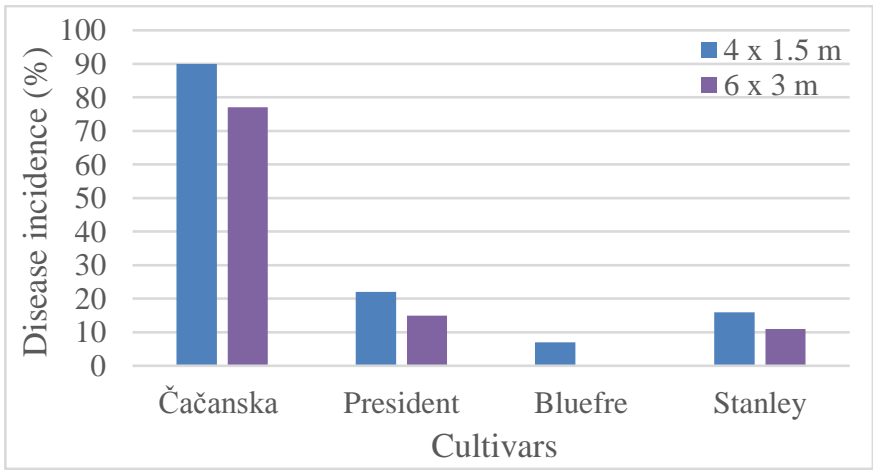

Figure 5. Incidence of blackhorn dotty caused by Polystigma rubrum in 2017 (Debrecen-Pallag) 
The most susceptible cultivar was cv 'Čačanska lepotica' with the highest disease incidence (90\%) in the $4 \times 1.5 \mathrm{~m}$ spacing. Disease incidence of this cultivar was lower (78\%) in the $6 \times 3 \mathrm{~m}$ spacing which was significantly less than in the $4 \mathrm{x}$ $1.5 \mathrm{~m}$ spacing. The least susceptible cultivar was 'Bluefre' and symptoms were observed only in the spacing of $4 \times 1.5 \mathrm{~m}$. The disease incidence of cv 'President' was similarly low to cV 'Stanley' in both spacings.

\section{Conclusions}

Our study demonstrated that there were significant differences in disease incidences of Polystigma rubrum and Stigmina carpophila between tree spacings and cultivars. However, the disease levels were dependent on the weather conditions of the years. These results provide that not only year and cultivar but tree spacings also play an important role in the level of fungal disease on plum.

\section{Acknowledgements}

This research was partly supported by grants of the Hungarian Scientific Research Fund (K78399 and K108333) and the NKTH-OM-00227/2008 as well as by a by the European Union and the State of Hungary, co-financed by the European Social Fund in the framework of TÁMOP-4.2.4.A/ 211/1-2012-0001 'National Excellence Program' under project number A2-SZJ-TOK-13-0061. János Bolyai Research Fellowship awarded to Imre J. Holb. The research/thesis/dissertation is supported by the EFOP 3.6.1-162016-00022 project. The project is co-financed by the European Union and the European Social Fund.

\section{References}

Adaskaveg, J. E., Ogawa, J. M., Buttler, E. E. (1990): Morphology and ontogeny of conidia in Wilsonomyces carpophilus gen. nov. and comb. nov., causal pathogen of shot hole disease of Prunus species. Mycotaxon 31:275-290.

Adaskaveg, J. E. (1995): Conidial morphology, host colonization, and development of shot hole of almond caused by Wilsonomyces carpophilus. Canadian Journal of Botany 73:432-444. https://doi.org/10.1139/b95-044
Ahmadpour, A., Ghosta, Y., Javan-Nikkhah, M., Fatahi, R., Ghazanfari, K. (2009): Isolation and pathogenicity tests of Iranian cultures of the shot hole pathogen of Prunus species, Wilsonomyces carpophilus. Australasian Plant Disease Notes 4:133-134. DOI: 10.1071/DN09054

Borovinova, M. (2002): Susceptibility of plum cultivars to red leaf spot Polystigma rubrum (persoon) de candolle. Acta Horticulturae, 577:255-258. https://doi.org/10.17660/ ActaHortic. 2002.577.43

Bubici, G., D'amico, M., Cirulli, M. (2010): Field reactions of plum cultivars to the shot-hole disease in southern Italy. Crop Protection 29(12):1396-1400. DOI: 10.1016/j.cropro. 2010.07.021

Földes L. Sz., Nagy M., Varga M. (2015): A szilva védelme. (Plum plant protection) Növényvédelem. 51 (3):105-130.

Holb I. J. (2005): A gyümölcsösök és a szőlő ökológiai növényvédelme. (Organic plant protection of fruits and grape) Mezőgazda Kiadó, Budapest 330 p.

Ivanová, H., Kalocaiová, M., Bolvansky, M. (2012): Shothole disease on Prunus persica - the morphology and biology of Stigmina carpophila. Folia Oecologica, 39(1):21-27.

Mika, A., Buler, Z., Chlebowska, D. (1998): The effect of training systems and planting density on growth and fruiting of plum trees grafted on two rootstocks. Acta Horticulturae 478:107-112. https://doi.org/10.17660/ActaHortic.1998.478.16

Milosevic, T., Zornic, B., Glisic, I. (2008): A comparison of low-density and high-density plum plantings for differences in establishment and management costs, and in returns over the first three growing seasons - a mini-review, The Journal of Horticultural Science and Biotechnology, 83(5):539-542. DOI: $10.1080 / 14620316.2008 .11512419$

Teviotdale, B. L., Viveros, M., Freeman, M.W., Sibbett, G. S. (1989): Effect of fungicides on shot hole disease of almonds. California Agriculture. 43(3):21-23.

Yousefi, A., Hagian Shahri, M. (2014): Shot hole disease, survival and pathogenicity of the causal agent on stone fruit trees of North East Iran. Journal of Crop Protection 3 (4): 563572. 